\title{
Finding lighting balance within the ecosystem of Taman Teras Cikapundung
}

\author{
R.H.W. Abdulhadi \& M.T.M. Raja \\ Telkom University, Bandung, Jawa Barat, Indonesia \\ M. Akkaya \\ Kadir Has University, Istanbul, Turkey
}

\begin{abstract}
Taman Teras Cikapundung park restoration has succeeded in creating an open space for public use. This park has various functions, as a gathering place, improving aspects of economics and as nature conservation. From an economic point of view, this park is considered to be able to create new values for the community, however from the preservation point of view, deeper observation is needed, especially in terms of lighting design. The research was conducted with comparative observations through field studies and literature, by making comparisons between existing conditions and how lighting should emphasize nature conservation. From this study it was found that the lighting in this park still prioritizes recreational and economic functions without paying attention to conservation. This can be seen from the selection of lighting, through the direction of the light, spectral distribution, and shielding that is not in accordance with the provisions of nature conservation.
\end{abstract}

Keywords: lighting pollution, lighting Taman Teras Cikapundung, nature conservation, lighting and nature conservation,

\section{INTRODUCTION}

The restoration of the Teras Cikapundung Park is an effort initiated by Balai Besar Wilayah Sungai Citarum with the Bandung's regional government to organize, restore its infrastructure in the form of open spaces with several functions such as educational facilities, recreational facilities, commercial space, and as a means of nature conservation (Direktoran Jenderal Penataan Ruang Departemen Pekerjaan Umum 2008). The park is open to the public and can be accessed late into the night. The atmosphere at night is added with the lighting design that is presented. One lighting design which catches the attention is the dancing fountain equipped with colored lighting which adds value to recreational functions. Other existing lighting features serve as a safety and security factor for visitors. As a park that has a fairly complex function, the balance between education, recreation, commerce, and conservation functions is important.

Based on location, this park is located on the banks of the Cikapundung River and very close to the river area and the green area of Babakan Siliwangi, in which there are many flora and fauna ecosystems along the river banks which should also be part of conservation. One way that this has been done in the context of nature conservation is preservation of urban forests, maintaining the cleanliness of the forests and river streams from waste, and fish breeding in existing ponds. In terms of function, this has been able to provide benefits to the community, but for the preservation of nature and ecosystems that live in urban forests and river streams and riparian area, there are other problems that need to be addressed.

The problems that arise in this park are caused by activities that function until the night, where lighting is a must for the safety and comfort of visitors. On the other hand, lighting is a problem 
for the riverbank ecosystem for both floral and fauna (Bennie et al. 2016). Riverbank ecosystems are important to humans; the loss of ecosystems in riverbank areas will cause the loss of aesthetic, economic, recreational, and other characteristics that have human value (National Research Council 2002). Another disadvantage for the ecosystem is changes in the food chain that occur in riverbank areas, so that the balance of the ecosystem is disturbed (Manfrin et al. 2017). With the destruction of the food chain, it will directly affect humans. In fact, research from several places in the river area shows that the breakdown of the food chain will cause the growth of algae, and in worst conditions the river oxygen levels decrease and damage fish habitats, causing an unpleasant odor (Longcore \& Rich 2016). This, of course, will have an impact on humans by losing the economic and recreational aspect. In terms of area coverage, this park is not too large, so that artificial lighting that occurs at night will have a significant impact on the riverbank ecosystem (Longcore \& Rich 2016).

The purpose of this study is to provide an evaluation and solution to the lighting design at Teras Cikapundung in relation to its function as a conservation area. Evaluation and solution are to be met in terms of armature selection, and color spectrum of the light used in relation to the balance of the garden's functions as nature conservation.

\section{RESEARCH METHODOLGY}

The research method used is comparative observation. Observations were made by paying attention to the type of luminaire, light color temperature in each luminaire, lighting control device, and its light distribution. The results from these observations are then compared with lighting standards for environmental conservation. This research method is used to provide an evaluation of lighting and the impact that occurs in this park in the field of conservation so that it is expected to provide improvements in the future.

Data collecting was carried out through direct observation at the park. List of luminaires with its specification such as types of luminaires, color temperature, light control system, and light distribution is then processed through table list as data set.

Through data set table, a lighting condition at the park can be seen. Furthermore, a comparison through accordance of luminaires, color temperature, lighting control device, and its lighting distribution as ecosystem friendly lighting can be compared. Comparison was using a standard from the Australian Government Department of Environment and Energy 2019. The National Light Pollution Guidelines for Wildlife has a broad and clear statement about how good lighting should be applied to preserve ecosystem.

Table 1. Data set luminaires.

\begin{tabular}{|c|c|c|c|c|}
\hline No. & $\begin{array}{l}\text { Types of } \\
\text { Luminaires }\end{array}$ & Color temperature & $\begin{array}{l}\text { Lighting control } \\
\text { device }\end{array}$ & Lighting distribution \\
\hline 1 & $\begin{array}{l}\text { Pole luminaires } \\
\text { for general } \\
\text { illumination }\end{array}$ & $5000 \mathrm{~K}$ & none & $\begin{array}{l}\text { downward wide (symetrric } \\
45 \text { degree) }\end{array}$ \\
\hline 2 & $\begin{array}{l}\text { Floor mounted } \\
\text { uplight for trees }\end{array}$ & $3600 \mathrm{~K}$ & None & $\begin{array}{l}\text { upward-Wide (symmetric } \\
45 \text { degree) }\end{array}$ \\
\hline 3 & Bollard at bridge & $3600 \mathrm{~K}$ & $\begin{array}{l}\text { Shielded with } \\
\text { opaque glass }\end{array}$ & difused \\
\hline 4 & $\begin{array}{l}\text { Perimeter } \\
\text { lighting with } \\
\text { LED strip }\end{array}$ & Blue light & None & diffused \\
\hline 5 & $\begin{array}{l}\text { Orientation } \\
\text { lighting }\end{array}$ & $3600 \mathrm{~K}$ & Indirect light & downward \\
\hline 6 & Flood lighting & $3000 \mathrm{~K}$ & Flood light & $\begin{array}{l}\text { upward and downward > } \\
45 \text { degree }\end{array}$ \\
\hline
\end{tabular}




\section{RESULT AND DISCUSSION}

Lighting mitigation which are used on different habitat should be considering five aspects. Aspects which considered to be important are the how much light for human to perceive its surrounding in terms of safety and consideration to nature, spectrum of lamp, intensity of light, direction of light, and duration (Longcore\& Rich 2016). Based on the survey at the park, lighting at Teras Cikapundung has several functions. The main lighting is in the form of pole lighting which is used to provide general lighting and provide a safety factor in the garden. The type of lamp used are pole luminaires and provides lighting in a wide direction, with a light spread of more than $45^{\circ}$ downward. This lamp functions as the lighting for the parking lot bordering the river area, lighting the sitting area, and the amphitheater. The type of lamp used is an LED with the color spectrum used is cold white or around $4000 \mathrm{~K}$.

The use of this pole lighting is considered to meet the standard of illumination at conservatory area in terms of need, light direction, light intensity of light, and duration, but in terms of spectrum which related to the types of lamp which is used is not correct, the use of LED light in cold color temperature ca. $4000 \mathrm{~K}$ contain much blue spectrum in it is considered not appropriate for conservation. The use of LED lighting could be altered with high pressure sodium lamp, or warm white LED lamp which has long wavelength (Pawson \& Bader 2014.)

The second lighting is accentuation lighting. The type of luminaire which is used are floor mounted luminaires and provides lighting in a wide direction, with a light spread of more than $45^{\circ}$ upward. This lamp functions as the lighting for accentuating trees. The type of lamp used is an LED with the color spectrum used is warm white or around $3600 \mathrm{~K}$.

The light used is an LED type but with a lower color temperature, around $3600 \mathrm{~K}$, thus not too harmful for the environment. The incorrect application comes from the type of luminaire which is used; there should be a proper shielding to minimize light spill from the luminaire which causes a lot of light to be wasted. Apart from having a harmful impact on pollution for nature, also in a certain direction of view it will cause glare for visitors (Australian Government Department of Environment and Energy 2019)
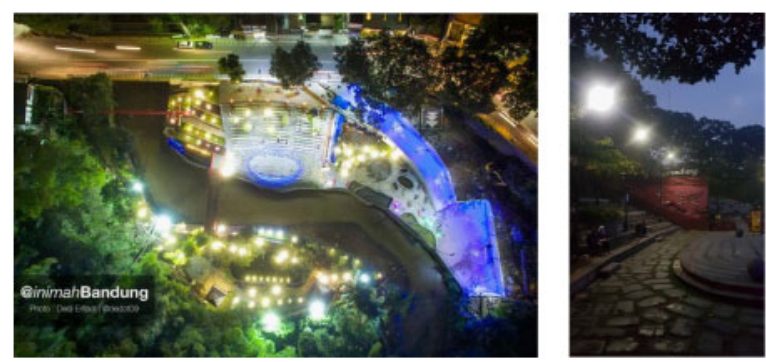

Figure 1. General illumination at Teras Cikapundung in the form of pole lighting.
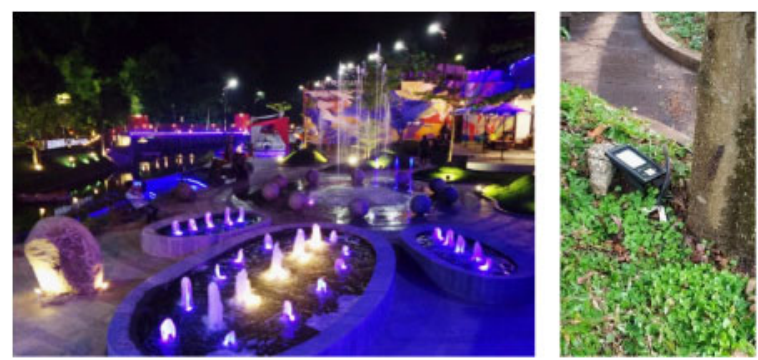

Figure 2. Accent illumination at trees at Teras Cikapundung in the form of floor-mounted up-lighting. 

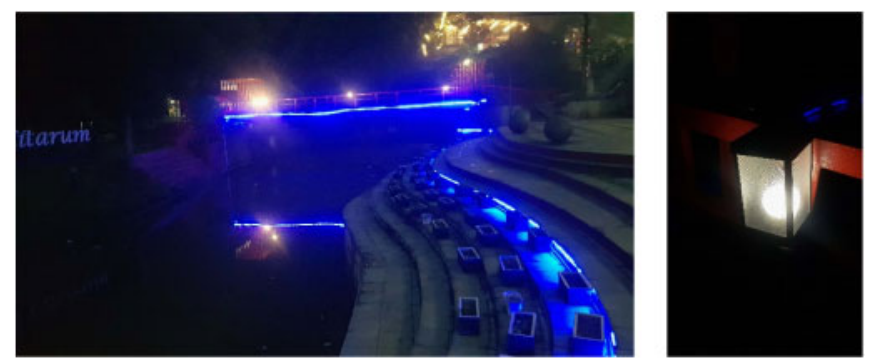

Figure 3. Perimeter illumination at the amphitheater and bridge at Teras Cikapundung in the form blue LED strip light, and bollard.

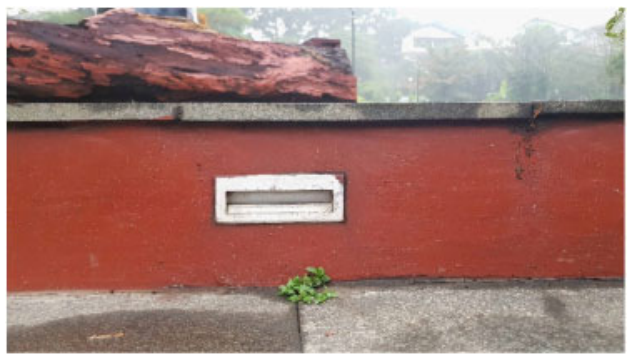

Figure 4. Orientation illumination at stairs at Teras Cikapundung in form of recessed lighting.

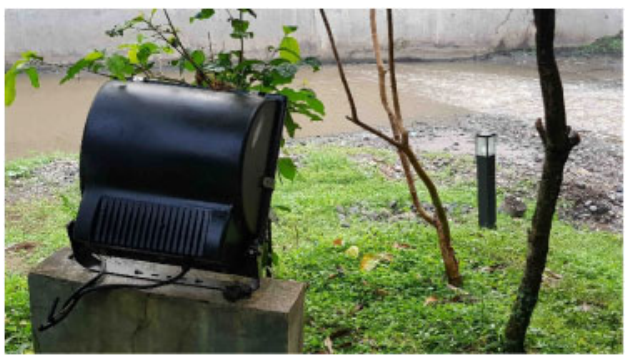

Figure 5. Flood lighting directed to river stream.

The third lighting used is a lighting parameter that functions to limit the pedestrian area to the river area, including those used under bridges. Perimeter lighting is uses two methods: by forming area boundaries through the use of LED strips and the use of light bulbs that are arranged to limit pedestrian areas and river areas.

The incompatibility of this perimeter illumination using LED strip lamps concerning environmental issues is the application which is not hidden or integrated to features at parks and the use of blue colored light. The use of blue as the color of choice has a very bad impact, especially on the perimeter and under the bridge area (Pawson \& Bader, 2014). The use of bollard lamps in the perimeter area is still considered adequate and can be used because the wrapping material used around the lamp is opaque glass so that it can still be tolerated, and the color of the lamp used is warm white or around $3600 \mathrm{~K}$.

The other lighting in this area that is felt to be quite good is the orientation light on several steps so that the distribution of light is specifically directed toward the stairs. The use of directional light minimizes light spill and helps with visitor orientation. 
The use of special lighting for recreational such as dancing fountain is not considered to be harmful, since it is not always turned on unlike other lighting which is always turned on. Another lighting application that is considered to be harmful is the use of floodlighting directed at the river and trees in the nature area. The lamp that is used is high pressure sodium, which has yellow light spectrum, but the direct illumination is considered to be harmful for the ecosystem.

\section{CONCLUSION}

In this research it was found that the lighting design at Teras Cikapundung Park as a whole cannot be said to be appropriate for nature conservation. Lighting is only intended for the safety and comfort of visitors by prioritizing aspects of recreation and economic value, but in the long run these aspects can be disrupted by disruption of the ecosystem in this park. The need for humans to perceive and have activities should be balanced with the conservation of nature, especially at a park that has a close relation to nature and has a conservatory function. Inappropriate use of lighting distribution, spectrum, or choice of lamp, and lack of shielding will become harmful for the park's ecosystem.

The form of research by prioritizing the balance between ecosystems and humans is a form of research that is flared discussed in developed countries. The development of technology and applications in lighting is then questioned in relation to the environment. The strength of this research is that it can provide practical solutions for lighting at Teras Cikapundung Park, but it still has shortcomings due to the need for complete quantitative data in terms of lamp spectrum, and more in-depth lighting simulations, as well as relationships with other researchers, especially from the environmental field to provide more optimal result. Recommendations for further research can be in the form of solution to provide smart lighting system or lighting distribution control system which can be adjusted to the occupant of Taman Teras Cikapundung and its environment, thus creating a balance between recreation, finance, and the environment.

\section{ACKNOWLEDGMENT}

We would like to thank those who helped carry out this research. Our gratitude is addressed to Telkom University lecturers who helped develop and become a source of inspiration in this research. We also express our gratitude to the Bandung's City Government and Dinas Pekerjaan Umum who have worked hard to realize, develop, and manage the Taman Teras Cikapundung. We would also like to thank the community and parties who have managed to create a Cikapundung terrace garden; without good management this park would not have become our source of inspiration.

\section{REFERENCES}

Australian Government Department of Environment and Energy. 2019. National Light Pollution Guidelines for Wildlife.

Bennie, J., Davies, T.W., Cruse, D., and Gaston, J. 2016. Ecological effects of artificial light at night on wild plants. Journal of Ecology 104(3):611-620.

Direktoran Jenderal Penataan Ruang Departemen Pekerjaan Umum. 2008. Pedoman Penyediaan Dan Pemanfaatan Ruang Terbuka Hijau (RTH) Di Kawasan Perkotaan Permen PU No. 5/PRT/M/2008. Indonesia.

Longcore, T. and Rich, C. 2016. Artificial Night Lighting and Protected Lands: Ecological Effects and Management Approach.

Manfrin et al. 2017. Artificial Light at Night Affects Organism Flux Across Ecosystem Boundaries and Drives Community Structure In The Recipient Ecosystem.

National Research Council. 2002. Riparian Areas: Functions and Strategies for Management. Washington, D.C: The National Academies Press.

Pawson, S.M. and Bader, M.K. 2014. Led lighting increases the ecological impact of light pollution irrespective of color temperature. Ecological Applications. 